UDC 633.15-152]:631.559

COBISS.SR-ID 253153548

Original research paper

Acta Agriculturae Serbica, Vol. XXII, 44 (2017); 157-167

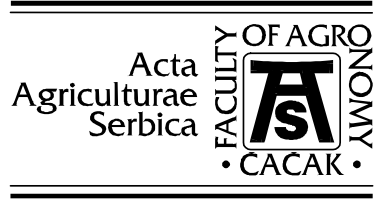

\title{
Grain yield of maize hybrids at different plant densities
}

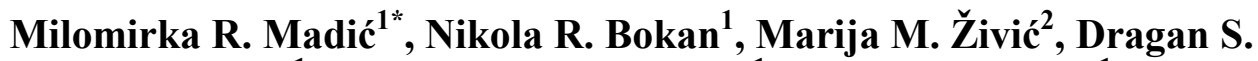 \\ Đurović ${ }^{1}$, Aleksandar S. Paunović ${ }^{1}$, Dalibor D. Tomić ${ }^{1}$ \\ ${ }^{1}$ University of Kragujevac, Faculty of Agronomy Čačak, Cara Dušana 34, Čačak, \\ Republic of Serbia \\ ${ }^{2}$ Textile Technology and Agricultural School Despot Đurad, 17. October 40, \\ 11300 Smederevo, Republic of Serbia \\ Corresponding author: mmadic@kg.ac.rs
}

\begin{abstract}
Field trials with 12 maize hybrids belonging to FAO maturity groups 500, 600 and 700 were established under the agro environmental conditions of Smederevo in 2010 and 2011 to analyse grain yield and moisture content at different plant densities. The hybrids were sown in two independent trials in the two years at 51,000 and 62,000 plants $\mathrm{ha}^{-1}$, respectively, in a randomised block design with three replications. More favourable maize growing conditions i.e. more moderate air temperatures during the growing season, a more even distribution of precipitation and more rainy days were recorded in 2010 than in 2011, which had much lower precipitation amounts, particularly during July and August i.e. critical development stages (flowering and fertilization) of these hybrids. Grain yield of all maize hybrids was higher in 2010, mostly as the result of greater amounts of precipitation and their more even distribution during the growing season. In both years, significantly higher grain yields were obtained by FAO 600 maize hybrids. Grain yield in 2010 was significantly higher at the higher plant density in FAO 500 hybrids, as opposed to FAO 600 hybrids, which showed no significant difference in grain yield across plant densities. Grain moisture content at harvest did not significantly differ between plant densities in either year. Somewhat higher values for grain moisture at harvest in 2010 were recorded for FAO 600 hybrids. In 2011, there were no significant differences in grain moisture content among hybrids, nor between plant densities, mostly due to the very low amount of precipitation in the second part of the growing season.
\end{abstract}

Received 20 October 2017 Accepted 27 October 2017 
Key words: grain yield, hybrids, maize, planting densities

\section{Introduction}

Maize has a very high biological yield potential, and is classified among crops which produce the largest amount of organic matter per unit area. The main economic importance of maize stems from its diverse utilisation as food, feed and raw material for industrial applications. Maize grain contains about $70 \%$ of starch on average, which makes it a highly suitable feedstock for bioethanol production (Semenčenko et al., 2015). Globally, maize ranks third in acreage, second in total production and first in grain yield per unit area. In Serbia, maize is the most widely grown field crop, covering about 1,300,000 ha of land, with a total grain production ranging between 4 and 7 million tons (Jocković et al., 2009). Most of modern maize hybrids grain yield increase comes from increased plant densities.

New maize hybrids are more cost-effective in using water and nutrients and are, hence, tolerant to increased plant densities (Stojaković et al., 1996). High yield potential of maize hybrids is best achieved at 550-700 $\mathrm{mm}$ precipitation supplied to plants during the growing season (Filipović et al., 2015). However, in most maize producing regions in the Republic of Serbia, there is a precipitation deficit of 200 $\mathrm{mm}$ on average, which has an adverse effect on maize growth and development. One way to reach a compromise and meet both producers' and breeders' interests is to classify crop producing regions based on their geographic, climatic and soil conditions and hybrid recommendations for each individual region (Babic et al., 2013). The regionalisation model enables identification of the highest-yielding and most stable genotypes under different environments and identification of the so-called ideal genotype and ideal test location (Gauch, 2006; Yan et al., 2007; de Oliveira et al., 2010; Babić et al., 2010; Mitrović et al., 2012). As stressed by Annicchiarico (2009), breeding for wide adaptability and breeding for high stability and reliability can sometimes be equated, when both stability and reliability indicate a consistently good grain yield response under diverse environments. Only an adaptive response to location, geographic region, agricultural practices or other factors controlled or anticipated before sowing can be used through the selection and production of specifically adapted genotypes.

Breeding success is dependent on the ability to provide genotypes whose phenotypes are reliably superior in terms of yield and/or quality under diverse environments (Malosetti et al., 2013). Phenotype is commonly considered to be the value of a trait at the end of the growing season. This final value of the trait is the sum of numerous causal interactions between genotype and plant development conditions. The objective of this study was to evaluate the grain yield potential of leading domestic maize hybrids grown at two plant densities over a period of two years under the agroenvironmental conditions of Smederevo. Given the grain yield potential of maize hybrids and their variability 
across experimental years and plant densities, hybrids showing the lowest variability, in addition to achieving satisfactory yields, can be recommended for a particular region.

\section{Materials and methods}

\section{Experimental material}

The experiment was established near Smederevo (40 $30^{\circ} \mathrm{N}$ and $20^{\circ} 57^{\prime} \mathrm{E}$, $99 \mathrm{~m}$ a.s.1.) in 2010 and 2011, and involved 12 promising maize hybrids belonging to FAO maturity groups $500-600$ i.e. 6 hybrids created by the Maize Research Institute, Zemun Polje (ZP 505, ZP 544, ZP 600, ZP 606, ZP 666, ZP 684 ) and 6 hybrids released by the Institute of Field and Vegetable Crops, Novi Sad (NS 5043, NS 540, NS 6010, NS 6030, NS 640, NS 7020). In both years, the hybrids were sown in two separate trials at two plant densities (D1 $=51,000$ and D2 $=62,000$ plants $\mathrm{ha}^{-1}$ ) in a randomised block design with three replications. Wheat was used as the preceding crop in both years. Harvest of the preceding crop was followed by deep ploughing, through which $20 \mathrm{t} \mathrm{ha}^{-1}$ manure and 300 $\mathrm{kg} \mathrm{ha}{ }^{-1}$ NPK fertiliser were incorporated into the soil. Immediately before sowing, seedbeds were prepared by a seedbed conditioner. Seeds were sown on 17 April 2010 and 10 April 2011. Inter-row spacing at both plant densities was $70 \mathrm{~cm}$, and intra-row spacing was $28 \mathrm{~cm}\left(51,020\right.$ plants ha $\left.^{-1}\right)$ and $23 \mathrm{~cm}(62,112$ plants $\left.\mathrm{ha}^{-1}\right)$ at the first and second plant densities, respectively.

Two rows of each hybrid were planted, with 27 plants per row (two grains per hill), excluding the first and last plants from analysis (a total of 50 plants per plot). Plot size was $9.8 \mathrm{~m}^{2}$ and $8.05 \mathrm{~m}^{2}$ at the first and second plant densities, respectively. Fifty plants per hybrid were analysed for grain yield across plant densities and replications. Upon harvest, the ears harvested from the main plot (50 plants) were weighed, and a sample of 5 ears was used for the determination of cob proportion and grain moisture percentage.

Results were subjected to a two-factor analysis of variance (with plant density and hybrid as factors), and individual differences were assessed by the LSD test, using SAS/STAT (SAS Institute, 2000). 


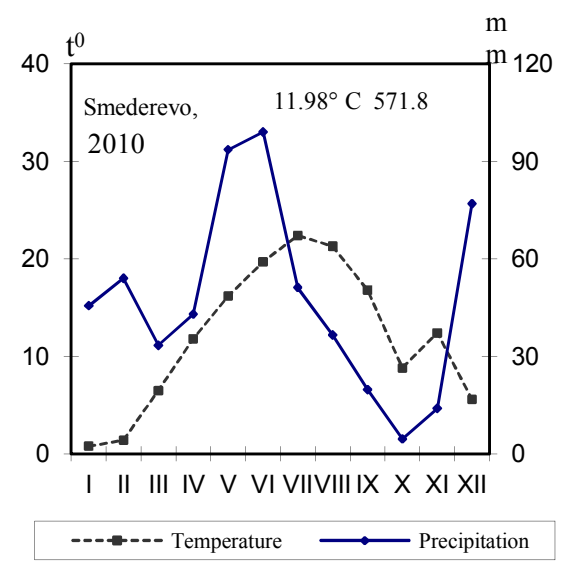

Graphic 1. Climate diagram for 2010 for Smederevo

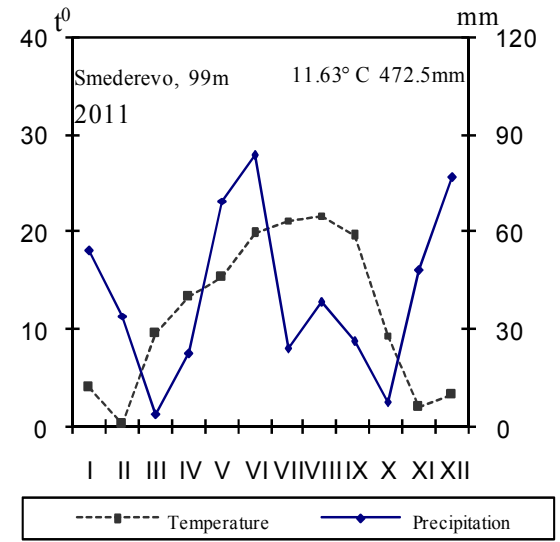

Graphic 2. Climate diagram for 2011 for Smederevo

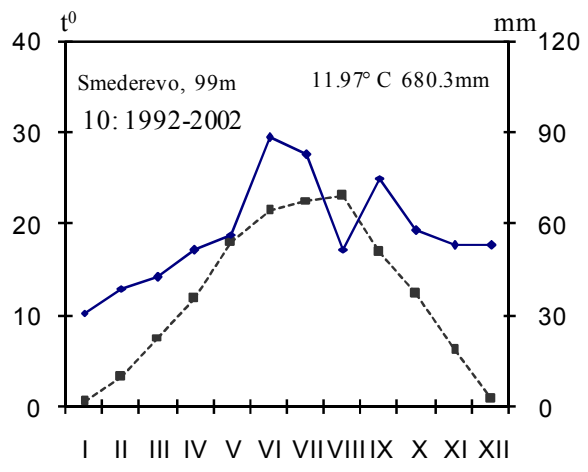

-.--- Temperature Precipitation

Graphic 3. Climate diagram for long-term average 1992-2002 for Smederevo

\section{Weather conditions}

The Smederevo region has a temperate continental climate. During the research, the average air temperature was close to the long-term average, and precipitation was unevenly distributed across months. The growing season of 2010 was warmer than typical for the region, with precipitation unevenly distributed (Graphic 1). Precipitation total was lower by $108 \mathrm{~mm}$ in 2010 and by $208 \mathrm{~mm}$ in 2011 compared to the long-term average (Graphics 1, 2 and 3). Precipitation deficits in the second half of July and in August, and high air 
temperatures in 2011 accelerated the maturation of maize plants, thus affecting grain yield (Graphic 2).

\section{Results and discussion}

Grain yield of all hybrids, regardless of plant density, was higher in 2010 (Table 1), mostly as the result of higher amounts of precipitation and their more favourable distribution over the growing season. Regardless of hybrid, a significantly higher grain yield in 2010 was obtained at the higher plant density, compared to 2011, when grain yield was higher at the lower plant density. The significantly lower grain yield in 2011 at the higher plant density was mostly associated with the substantially lower amount of precipitation and longer dry periods in the second half of the growing season, with plants individually receiving more water at the lower plant density. This led to higher grain yield per plant and per unit area. A favourable distribution of precipitation, along with appropriate agricultural operations, is far more important for grain yield and stability compared to low precipitation totals during the growing season (Ma et al., 2012). In 2010, grain yield was significantly higher at the higher plant density, mostly due to the higher amount of precipitation and its more even

distribution. Regardless of plant density, the highest grain yield was achieved by ZP 606 and NS 6010 hybrids in 2010, and by ZP 666, ZP 606 and NS 6030 in 2011. FAO 600 hybrids showed somewhat better performance than FAO 500 hybrids. At the lower plant density, significantly higher grain yields in 2010 were obtained by ZP 666 hybrid only (Graphic 4), and by NS 6030, NS 606 and ZP 666 in 2011 (plant density/hybrid interaction) (Graphic 5).

FAO 600 hybrids showed somewhat better performance than FAO 500 hybrids. At the lower plant density, significantly higher grain yields in 2010 were obtained by ZP 666 hybrid only (Graphic 4), and by NS 6030, NS 606 and ZP 666 in 2011 (plant density/hybrid interaction) (Graphic 5).

Significantly higher grain yields at the higher plant density in 2010 were obtained by FAO 500 hybrids (ZP 505, NS 540, ZP 544), ZP 600 and NS 6010, whereas the same hybrids in 2011 showed no difference in grain yield between plant densities. As found by Stojaković et al. (2010) in their analysis of macrotrials with 15 hybrids in 30 different locations in Serbia, FAO 500 and FAO 600 hybrids had greater grain yields and lower grain moisture contents compared to FAO 700 hybrids, suggesting that the temperature sum in Central Serbia is a determining factor when choosing maize hybrids. Weather conditions during the summer months (June, July and August) have an important effect on grain yields of maize. Using drought tolerant hybrids and avoiding improvised cultural practices could mitigate the consequences of stress induced by unfavourable weather (Kovačevič et al., 2010). 
Table 1. Grain yield of maize hybrids $\left(\mathrm{t} \mathrm{ha}^{-1}\right)$ in 2010 and 2011 at different plant densities D1 (51,000 plants ha $\left.{ }^{-1}\right)$ and D2 (62,000 plants ha $\left.{ }^{-1}\right)$.

\begin{tabular}{llll}
\hline & & 2010 & 2011 \\
\hline Density & $\mathrm{D}_{1}$ & $7.207 \mathrm{~b} *$ & $5.818 \mathrm{a}$ \\
& $\mathrm{D}_{2}$ & $8.104 \mathrm{a}$ & $5.488 \mathrm{~b}$ \\
\hline Hybrid & NS 5043 & $7.855 \mathrm{bcd}$ & $4.952 \mathrm{e}$ \\
& ZP 505 & $7.382 \mathrm{cde}$ & $5.624 \mathrm{cde}$ \\
& NS 540 & $7.300 \mathrm{de}$ & $3.982 \mathrm{f}$ \\
& ZP 544 & $6.891 \mathrm{e}$ & $5.416 \mathrm{de}$ \\
& ZP 600 & $8.065 \mathrm{ab}$ & $6.189 \mathrm{bc}$ \\
& NS 6010 & $8.587 \mathrm{a}$ & $5.896 \mathrm{bcd}$ \\
& NS 6030 & $7.994 \mathrm{abc}$ & $6.435 \mathrm{ab}$ \\
& ZP 606 & $8.587 \mathrm{a}$ & $6.341 \mathrm{ab}$ \\
& NS 640 & $7.168 \mathrm{e}$ & $4.168 \mathrm{f}$ \\
& ZP 666 & $7.220 \mathrm{de}$ & $7.017 \mathrm{a}$ \\
& ZP 644 & $7.341 \mathrm{cde}$ & $5.867 \mathrm{bcd}$ \\
& NS 7020 & $7.478 \mathrm{~b}-\mathrm{e}$ & $5.952 \mathrm{bcd}$ \\
\hline LSD 0.05 & Density (A) & $*$ & $*$ \\
& Hybrid (B) & $*$ & $*$ \\
\hline
\end{tabular}

*The values followed by different lowercase letters in columns are significantly different $(\mathrm{P}<0.05)$ in accordance with LSD test;

*F-test significant at $\mathrm{p}<0.05$

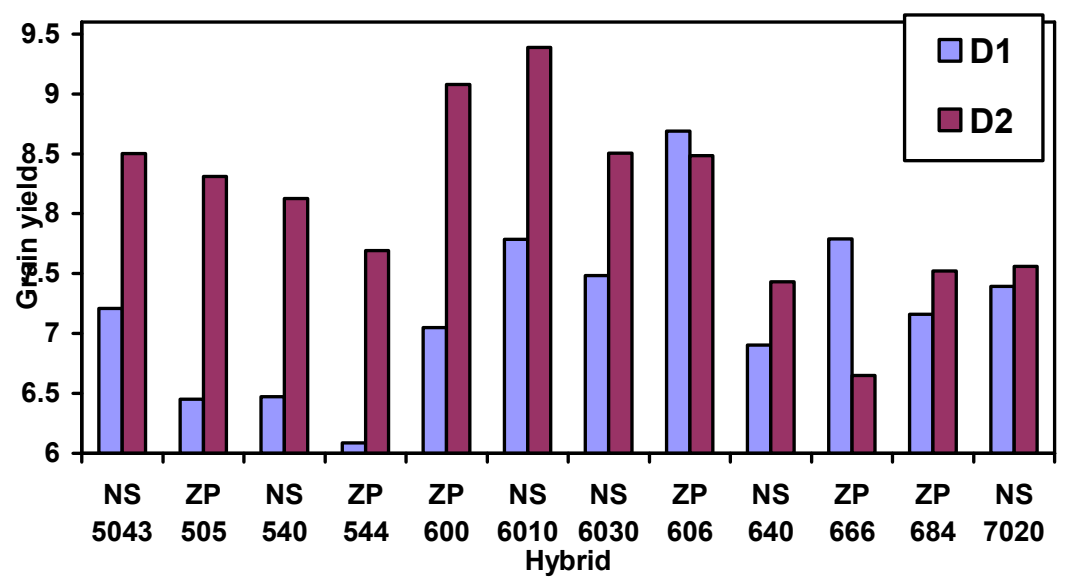

Graphic 4. Grain yield of maize hybrids $\left(\mathrm{t} \mathrm{ha}^{-1}\right)$ at different plant densities: D1 $\left(51,000\right.$ plants ha $\left.^{-1}\right)$ and D2 (62,000 plants ha $\left.{ }^{-1}\right)$ in 2010. 


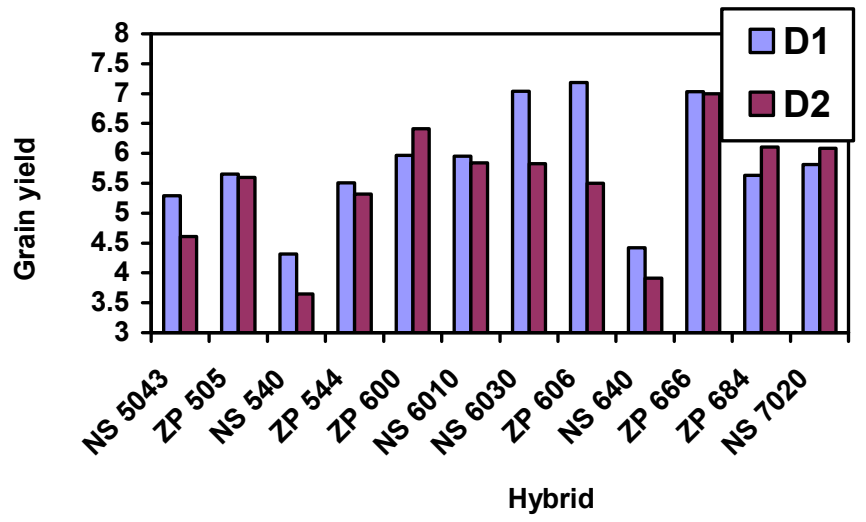

Graphic 5. Grain yield of maize hybrids $\left(t h a^{-1}\right)$ at different plant densities: D1 (51,000 plants $\left.\mathrm{ha}^{-1}\right)$ and D2 (62,000 plants $\left.\mathrm{ha}^{-1}\right)$ in 2011

Table 2. Grain moisture (\%) in maize hybrids at harvest in 2010 and 2011 at two plant densities D1 (51,000 plants ha $\left.{ }^{-1}\right)$ and D2 (62,000 plants ha $\left.{ }^{-1}\right)$

\begin{tabular}{llll}
\hline & & 2010 & 2011 \\
\hline Density & $\mathrm{D}_{1}$ & 19.19 & 15.032 \\
& $\mathrm{D}_{2}$ & 19.09 & 14.883 \\
\hline Hybrid & NS 5043 & $18.87 \mathrm{~d}^{*}$ & $15.033 \mathrm{bc}$ \\
& ZP 505 & $18.04 \mathrm{de}$ & $15.117 \mathrm{abc}$ \\
& NS 540 & $18.41 \mathrm{de}$ & $14.517 \mathrm{~cd}$ \\
& ZP 544 & $20.18 \mathrm{bc}$ & $14.567 \mathrm{~cd}$ \\
& ZP 600 & $16.79 \mathrm{f}$ & $13.867 \mathrm{~d}$ \\
& NS 6010 & $19.18 \mathrm{~cd}$ & $15.075 \mathrm{bc}$ \\
& NS 6030 & $19.18 \mathrm{~cd}$ & $15.217 \mathrm{abc}$ \\
& ZP 606 & $17.62 \mathrm{ef}$ & $15.900 \mathrm{a}$ \\
& NS 640 & $22.49 \mathrm{a}$ & $15.417 \mathrm{ab}$ \\
& ZP 666 & $20.54 \mathrm{~b}$ & $15.317 \mathrm{abc}$ \\
& ZP 684 & $20.36 \mathrm{bc}$ & $14.700 \mathrm{bc}$ \\
& NS 7020 & $18.05 \mathrm{de}$ & $14.767 \mathrm{bc}$ \\
\hline LSD 0.05 & Density (A) & ns & ns \\
& Hybrid (B) & $*$ & ns \\
\hline
\end{tabular}

*The values followed by different lowercase letters in columns differ significantly at $(\mathrm{P}<0.05)$ in accordance with the LSD test. * F-test significant at $\mathrm{p}<0.05$; ns - F-test non-significant 
Živanović et al. (2006) reported an increase in grain yield by $10.8-12.8 \%$ in FAO 600 and 700 hybrids, compared to FAO 400 and 500 hybrids. Moreover, the authors recorded a $5.2 \%$ decline in grain yield at low plant densities and a $2.6 \%$ increase at high plant densities relative to optimal plant densities. In a trial with FAO 100-700 maize hybrids (Petrović et al., 1988), the highest yields were obtained by FAO 300 hybrids, and yields of hybrids in higher maturity groups were comparable. Lower grain yields in FAO 700 were attributed to the insufficient moisture supply at critical periods of plant development.

The moisture content of maize grain at harvest showed no significant difference between plant densities in either year (Table 2). Regardless of plant density, grain moisture content in 2010 ranged between $16.76 \%$ (ZP 600) and $22.49 \%$ (NS 640). Somewhat higher values in 2010 were found in NS 640, ZP 666, ZP 684 and ZP 544 hybrids.

In 2011, grain moisture content was in the range of $13.87 \%$ (ZP 600) to $15.9 \%$ (ZP 606). The substantially higher amount of precipitation in the second part of the growing season in 2010 relavite to 2011 as the main reason for increased grain moisture content at harvest in all hybrids. As stressed by Filipović et al. (2014), the moisture content of maize grain at harvest has an important effect on grain yield. When analysing grain yield and its components in 11 maize hybrids exhibiting different lengths of the growing season (FAO maturity groups 300-700), Đurović et al. (2014) recorded significant differences among some hybrids and locations in grain moisture content at harvest, and significant interactions with the environment. Rapid moisture loss during maturation is induced both by climatic factors and by the agronomic traits of the plant itself. Maiorano et al. (2010), highlighted that maize grain composition can influence water availability during maturation. ORDAS et al. (1996) attributed the high moisture percentage at harvest to the lack of hybrid adaptability to an agroenvironment. Based on the results of a three-year trial with two sets of maize hybrids (I early and early to medium maturity hybrids and II full season maturity hybrids) at three planting dates, Magari et al. (1997) determined the characteristics of the genotype/environment interaction for ear moisture loss rate and found is missing significance for both groups of hybrids. Precipitation was the single climatic factor during the growing season which contributed to this interaction. Irrespective of differences among hybrids, the abovementioned fact and the different genotype responses to environmental factors led the authors to conclude that the nature of this interaction should be estimated for each genotype i.e. group of related hybrids.

\section{Conclusion}

Grain yield in both years was significantly higher in FAO 600 hybrids than in FAO 500 hybrids. In 2010, grain yield was significantly higher at the higher plant density in FAO 500 hybrids, when compared to late maturity hybrids whose 
yields were not significantly different across plant densities. Regardless of differences among hybrids, grain yields of all hybrids in 2011 were comparable across densities i.e. none of the hybrids gave significantly higher yields at the higher plant density.

The moisture content of maize grain at harvest showed no significant difference between the two plant densities in either year. Somewhat higher values for grain moisture content at harvest in 2010 were recorded for late maturity hybrids. In 2011, there were no significant differences in grain moisture content among hybrids, nor between plant densities, mostly due to the very low amount of precipitation in the second half of the growing season.

\section{Acknowledgments}

The research presented in this paper is part of projects TR 031092 and TR 031054 funded by the Ministry of Education, Science and Technological Development of the Republic of Serbia.

\section{References}

Annicchiarico P. (2009): Coping with and exploiting genotype-by environment interactions. (chapter 20, 519-564: In Plant breeding and farmer participation, (Eds: S. Ceccarelli, E.P. Gumaraes, E Weltzin).

Babić V., Babić M., Ivanović M., Kraljević-Balalić M., Dimitrijević M. (2010): Understanding and utilization of genotype-byenvironment interaction in maize breeding. Genetika, 42 (1): 79-90.

Babić V., Prodanović S., Babić M., Deletić N., Anđelković V. (2013): The identification of bands related to yields and stability in maize hybrids and their parental components. Genetika, 45 (2): 589-599.

de Oliveira, R.L., Von Pinho R.G., Balestre M., Ferreira D.V. (2010): Evaluation of maize hybrids and environmental stratification by the methods AMMI and GGE. Crop Breeding and Applied Biotechnology 10: 247-253.

Djurović D., Madić M., Bokan N., Stevović V., Tomić D., Ta nas k ović S. (2014): Stability parameters for grain yield and its component traits in maize hybrids of different FAO maturity groups. Joumal of Central European Agriculture, 15 (4): 199-212.

Filipovic M., M. Babić N. Delic G. Bekavac V. Babić (2014). Determination relevant breeding criteria by the path and factor analysis in maize. Genetika, 46(1): 49-58.

Filipović M., Ž. Jovanović M. Tolimir (2015). Directions in the selection of new ZP hybrids. XX Symposium on Biotechnology, Faculty of Agronomy, Čačak, 13-14 March 2015, Čačak. Proceedings, 20 (22): 7-13

G a u c h H. G. (2006): Statistical analysis of yield trials by AMMI and GGE. Crop Science 46:1488-1500.

Jocković Đ., Bekavac G., Purar B., Nastasić A., Malidža G., Dimitrijvić M., Đalović I. (2009): Maize breeding - ensuring continuity. Selection and Breeding XV (2): 19-32.

Kovačević V., Paunović A., Knežević D., Biberdžić M., Josipović M. (2010): Effect of weather on maize yields during 2000-2007. XV Symposium on 
Biotechnology, Faculty of Agronomy, Čačak, 26-27 March 2010, Proceedings, 15 (16): 13-19.

Ma Q., Wang L.Y., Zhou H., Hu G.Y., Jiang M.C., Yu W. (2012). Corn yield and yield stability under varying nutrient management, crop rotation, and rainfall. International Journal of Plant Production 6 (1): 73-92.

Magari R., Kang M.S., Zhang Y. (1997): Genotype by environment interaction for ear moisture loss rate in corn. Crop Science, 37: 774-779.

Malosetti M., Ribaut J.M., Van Euwijk F.A. (2013): The statistical analysis of multi-environment data: modeling genotype-by-environment interaction and its genetic basis. Frontiers in Physiology, 4: 44.

Maiorano A., Mancini M.C., Reyneri A. (2010): Water interactions in maize grain during maturation: differences among commercial hybrids. Maydica, 55:209-217.

Mitrović B., Stanisavljević D., Treskić S., Stojaković M., Ivanović M., Bekavac G., Rajković M. (2012): Evaluation of experimental maize hybrids tested in multi-location trials using AMMI and GGE biplot analyses. Turkish Journal of Field Crops 17 (1): 35-40.

Ordas A., Santiago J., Malvar R.A., Vales M.J. (1996): Six cycles of selection for adaptation in two exotic population of maize. Euphytica, 92: 241-247.

Petrović R., Stojnić O., Ivanović M. (1988): Maturity and yield potential and yield stability in maize (Zea mays L.). Genetika, 20: 269-279.

S A S / S T A T (2000): User's Guide, Version 9.1.3. SAS Institute Inc.

Semenčenko V., Radosavljević M., Mojović Lj., Terzić D., Milašinović- Šeremešić M., Todorović G. (2015): A genetic base of utilisation of maize grain as a valuable renewable raw material for bioethanol production. Genetika, 47 (1). 171-184.

Stojaković M., Ivanović M., Jocković Đ., Bekavac G., Purar B., Nastasić A., Stanisavljević D., Mitrović B., Treskić S., Lajšić R. (2010): NS maize hybrids in production regions of Serbia. Field and Vegetable Crops Research, 47 (1): 93-102.

Stojaković M., Jocković Đ., Bekavac G., Purar B. (1996): Breeding maize (Zea mays L.) for drought tolerance. Proceedings of the Institute of Field and Vegetable Crops, Novi Sad, 28: 27-38.

Yan W., Kang M.S., Ma B., Woods S., Cornelius P.L. (2007): GGE Biplot vs. AMMI analysis of genotype-by-environment data. Crop Science, 47:643-655.

Živanović LJ., Nenadić N., Nedić M., Kolarić L. (2006): Effect of plant density on grain yield in maize hybrids in different FAO maturity groups. Proceedings of the Institute PKB Agroekonomik, 12 (1-2): 39-46. 


\title{
PRINOS ZRNA HIBRIDA KUKURUZA U RAZLIČITIM GUSTINAMA SETVE
}

\author{
Milomirka R. Madić ${ }^{*}$, Nikola R. Bokan ${ }^{1}$, Marija M. Živić ${ }^{2}$, Dragan S. \\ Đurović ${ }^{1}$, Aleksandar S. Paunović ${ }^{1}$, Dalibor D. Tomić ${ }^{1}$ \\ ${ }^{1}$ Univerzitet u Kragujevcu, Agronomski fakultet u Čačku, Cara Dušana 34, \\ Čačak, Republika Srbija \\ ${ }^{2}$ Tekstilno tehnološka i poljoprivredna škola "Despot Đurađ", 17. oktobra 40 \\ 11300 Smederevo, Republika Srbija
}

\section{Rezime}

Poljski ogled sa 12 hibrida kukuruza FAO grupa zrenja 500, 600 i 700 postavljen je 2010 i 2011 godine u okolini Smedereva sa ciljem da se u postojećim agroekološkim uslovima analizira prinos i sadržaj vlage u zrnu kukuruza u različitim gustinama setve. Hibridi su zasijani u obe godine u dva nezavisna ogleda sa 51000 i 62000 biljaka ha $^{-1}$, po slučajnom blok sistemu u tri ponavljanja. $U$ toku vegetacije primenjena je uobičajena agrotetnika. Povoljniji uslovi za gajenje kukuruza, odnosno umerenije temperature u toku vegetacionog perioda, ravnomerniji raspored padavina, veći broj kišnih dana, bili su u 2010. godini, za razliku od 2011. godine u kojoj su zabeležene daleko manje količine padavina, naročito tokom jula i avgusta, kada kod ovih hibrida protiču kritične fenofaze razvoja (cvetanje i oplodnja). Značajno veći prinos zrna, u obe godine imali su hibridi FAO grupe zrenja 600. Značajno veći prinos zrna u 2010. godini zabeležen je u većoj gustini setve kod hibrida FAO grupe 500, za razliku od FAO grupe 600 kod kojih se prinos nije značajno razlikovao po gustinama. Sadržaj vode u zrnu kukuruza u vreme berbe nije se značajno razlikovao u različitim gustinama setve u obe godine. Nešto veću vlažnost zrna u vreme berbe 2010 . godine imali su hibridi FAO grupe 600 .

Ključne reči: prinos zrna, hibridi, kukuruz, gustina setve. 